\title{
INFLUENCE OF GENDER DIFFERENCE IN THE ANTIDEPRESSANT EFFECT OF FLUOXETINE IN MICE IN TAIL SUSPENSION TEST
}

\author{
ANKI $^{1}$, VAIBHAV WALIA ${ }^{2 *}$ \\ ${ }^{1}$ Division Pharmacology, PDM College of Pharmacy, Bahadurgarh, Haryana, India. ${ }^{2}$ Department of Pharmaceutical Sciences, Maharshi \\ Dayanand University, Rohtak, Haryana, India. Email: vaibhav.walia00@gmail.com
}

Received: 01 September 2016, Revised and Accepted: 03 October 2016

\section{ABSTRACT}

Aim: To determine the effect of gender difference in the antidepressant effect of fluoxetine (FLX) in mice in tail suspension test (TST).

Methods: Swiss albino mice of either sex were used and the depression-like behavior was measured by TST.

Results: The present study showed that there was a significant difference in the immobility period of male mice and female mice in TST. However, the antidepressant effect of FLX differs significantly in male mice and female mice in TST.

Conclusion: It has been concluded that the antidepressant effect of FLX in TST was affected by the gender difference as suggested by the results of the present study.

Keywords: Depression, Estrogen, Female, Fluoxetine, Mice, Serotonin.

(C) 2017 The Authors. Published by Innovare Academic Sciences Pvt Ltd. This is an open access article under the CC BY license (http://creativecommons. org/licenses/by/4. 0/) DOI: http://dx.doi.org/10.22159/ajpcr.2017.v10i1.15012

\section{INTRODUCTION}

Depression is a multifaceted heterogeneous disorder with the symptoms characterized at psychological, behavioral, and physiological levels [1]. Various symptoms of depression include anhedonia, loss of energy, low self-esteem, disturbed sleep or appetite, low energy, poor concentration, and suicidal intentions [2-4]. Alteration in the levels of the neurotransmitters has been found to be responsible for the pathogenesis of depression, but recently, it is suggested that the depression which is considered as a disorder that arises due to the imbalance in the levels of the neurotransmitters in the brain also arises due to the alterations in the activities of the various enzymes that catalyze the synthesis and metabolism of the neurotransmitters implicated in the pathogenesis of depression [5]. Serotonin (5-hydroxytryptamine [5-HT]) is a neurotransmitter that regulates mood and behavior [6], and its deficiency and reduced transmission contribute to depression [7]. Therefore, the drugs that correct the deficiency of 5-HT exerts antidepressant effect. Selective serotonin reuptake inhibitors (SSRIs) inhibit the reuptake of 5-HT into presynaptic neurons; increased its concentration in the synaptic cleft and are thus effective in the treatment of mood disorders, e.g., depression [8].

In rodents, the depression-like behavioral alteration can be measured by using tail suspension test (TST) [9,19]. In TST, animal initially shows some escape-oriented behavior but develops immobility after some escape attempts $[10,11]$. Immobility developed by the animals is the behavioral despair and represents symptom of depression [19,12]. Immobility thus reflects a specific state of mammalian defense repertoire known as arrested flight correlated with the psychological construct of entrapment in clinical depression [13-15]. This behavioral despair is similar to human depression and represents the psychomotor retardation in depressed patients $[10,16]$. Therefore, the reduction in the total immobility period indicates an antidepressant effect [17]. SSRIs are clinically proven antidepressants that reduce immobility period of animals in TST [9].

Sex differences have been found to influence the depressionrelated behavior [18]. Women experience major depression twice as compared to men [19-21] and in women depressive episodes are more protracted and recurs more frequently than men $[19,20]$. The main reason behind this is the cyclical change in the estrogen levels that increases their vulnerability to mood disorders [22-24]. The fact is further confirmed by the findings from the studies stated that the plasma estrogen levels are significantly lower among depressed women [21]. Results from the preclinical studies reported that the females are less immobile than males in FST at all stages of estrous cycle, [30], or the immobility is less particularly only during proestrus phase [31]. The findings from the observational and clinical studies supported a neurobiological basis for the multiple salutary effects of estrogen on mood during periods of estrogenic fluctuation [33]. Therefore, if the endogenous fluctuations in estrogen are responsible for negative effect, stabilizing estrogen levels via exogenous administration would exert the positive effect [34]. Estrogenic substances have been shown to exert the antidepressantlike effect in rodents in FST [27-29]. Estrogen is serotonergic agonist that acts via various mechanisms [32]. Furthermore, estrogen when administered systemically block 5-HT transporter (SERT) [26], and therefore, may modulate the antidepressant effects of the drugs that modulate the functioning of SERT. In the light of the above findings, a study was required to determine the effect of gender difference on the antidepressant effect of fluoxetine (FLX) in mice in TST.

\section{METHODS}

\section{Animals}

Swiss albino mice either sex were procured from Lala Lajpat Rai University of Veterinary and Animal Sciences, Hisar. All the animals were kept under controlled light and environmental conditions and had free access to food and water. Animals were allowed to acclimatize to laboratory conditions before the experiment. All the experiments were carried out between 9:00 and 16:00 hrs. The experimental protocols were approved by the Institutional Animal Ethics Committee, and care of the animals was carried out in compliance with the guidelines of the Committee for the Purpose of Control and Supervision of Experiments on Animals. 
Drugs and selection of dose

FLX was purchased from the Cadila Pharmaceuticals, Ahmedabad. The dose was selected according to the previous studies [35].

\section{Assessment of depression-like behavior in mice Tail suspension test}

TST is the most commonly used behavioral test for the assessment of depression-like behavioral alterations in mice. Each mouse was individually suspended at a height of $30 \mathrm{~cm}$ from the floor, by adhesive tape placed approximately $1 \mathrm{~cm}$ from the tip of the tail. Each mouse was then observed individually for a period of 6 minutes for the assessment of immobility period [19].

\section{Experimental protocol}

Swiss albino mice either sex were used in the present study. The mice were administered with FLX (20 mg/kg, i.p.) [35], and the depressionlike behavioral alterations in both male and female mice were measured using TST [19].

\section{Statistical analysis}

Data were analyzed by one-way ANOVA followed by Tukey's Post-hoc test. $p<0.05$ was considered as statistically significant.

\section{RESULTS}

Effect of gender difference of mice in TST

The effect of gender difference on the immobility period of male and female mice was shown in the Fig. 1. Immobility period of female mice was significantly greater than the male mice. There was a significant difference in the immobility period of FLX $(20 \mathrm{mg} / \mathrm{kg}$, i.p.) treated male mice and FLX $(20 \mathrm{mg} / \mathrm{kg}$, i.p.) treated female mice.

\section{DISCUSSION}

Depression is a chronic mental disease that affects more than $10 \%$ of population [36] and has become one of the most prevalent public health problems because of high rate of morbidity, recurrence, and mortality [37]. Depression is more common in females than males [38] and the women tend to have more depressive symptoms, during the times of large hormonal changes, suggesting that the hormonal changes plays a key role in the pathogenesis of depression $[39,40]$. In rodents, behavioral depression can be assessed using TST. The results of the present study revealed that the depression-like behavior were more in female mice as compared to male mice because the immobility period of female mice were significantly greater than the male mice in TST. Female rats have increased immobility in FST as compared to male rats as suggested by the previous studies [41]. Thus, female rodents show more depression-like behavior than males as suggested by the present study and is further confirmed by the findings of the previous studies reported in literature [41]. Estrous cycle in the females had

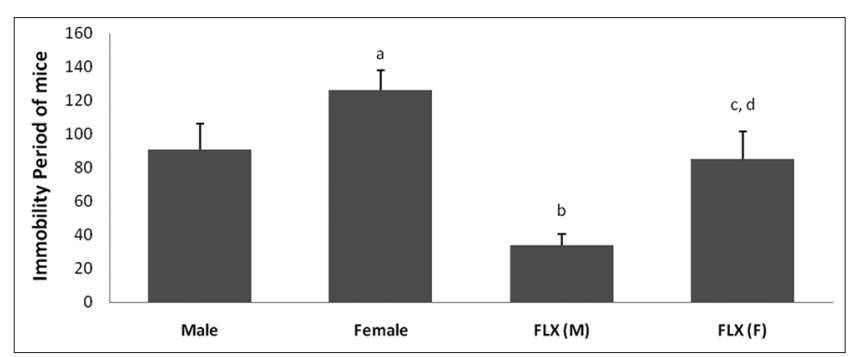

Fig. 1: Effect of different treatment on the immobility period male and female mice in tail suspension test. Values were expressed as mean \pm standard error of the mean, $n=5$ in each group. Data were analyzed by one-way ANOVA followed by Tukey's post-hoc test, $F(3,16)=20.342$. ${ }^{\text {a }}<<0.05$ significant difference from the male mice; ${ }^{b} \mathbf{p}<0.01$ significant difference from the male mice; ${ }^{c} \mathbf{p}<0.05$ significant difference from the female mice; ${ }^{\mathrm{d}} \mathbf{p}<0.01$ significant difference from the fluoxetine $(20 \mathrm{mg} / \mathrm{kg}$, i.p.) treated male mice been known to produce the phase-dependent effects on the depressive behavior $[46,47]$. This is one of the major reasons for the exclusion of female mice from behavioral testing because the hormonal fluctuation that occurs in the females during the estrous cycle; could potentially affect the animal behavior and complicates the data interpretation. Thus, sex/gender difference influence both the pathogenesis and evaluation of the psychiatric disorders such as depression and anxiety $[48,49]$. Depression is also mediated, by the alteration in hypothalamic-pituitary-adrenal axis (HPA) which is further modulated by the steroids of hypothalamic-pituitary-gonadal axis [25,42-45]. Neurotransmitters such as GABA and 5-HT that are mainly implicated in the pathogenesis of psychiatric disorders go through the functional changes along with the estrous cycle $[50,51]$. Estrogen contributes to the normal functioning of HPA axis [52-54], and the high levels of estrogen decrease the depressive behavior in females [31]. Furthermore, the estrogen therapy has been reported to exert antidepressant effects in perimenopausal and postmenopausal women [65]. The exact mechanism by which estrogen exerts antidepressant-like effect or reduces the depressive behavior is not known exactly but it is likely to be mediated by the activation of estrogen receptor beta [64]. Furthermore, the administration of estrogen upregulates 5-HT synthesizing enzyme, i.e. tryptophan hydroxylase $[55,56]$, downregulates SERT upon shortterm treatment [57], whereas upregulates SERT following long-term treatment [58], decreases the expressions of 5-HT metabolizing enzyme, i.e., monoamine oxidase [59], and reduces the expression of $5-\mathrm{HT}_{1 \mathrm{~A}}$ receptor in the various regions of brain $[60,61]$. Therefore, estrogen modulates both the density of 5-HT receptors and 5-HT turnover [62,63]. Thus, if estrogen influences 5-HT synthesizing and metabolizing enzyme, receptors, autoreceptors, and transporters, then it may also modulate the therapeutic effect of the drugs that influence the levels of 5-HT. To confirm this, we administered FLX (20 mg/kg, i.p.) to both male and female mice and the immobility period was determined by TST. Administration of FLX $(20 \mathrm{mg} / \mathrm{kg}$, i.p.) to both male and female mice significantly reduced the immobility period of both male and female mice as compared to their respective control. Also, the immobility period of FLX $(20 \mathrm{mg} / \mathrm{kg}$, i.p.) treated male mice was significantly less as compared to the immobility period of FLX (20 mg/kg, i.p.) treated female mice. Thus, there is a significant difference in the antidepressant effect of FLX (20 mg/kg, i.p.) in male and female mice. Therefore, it is suggested that the FLX $(20 \mathrm{mg} / \mathrm{kg}$, i.p.) produced more marked antidepressant effect in male as compared to female mice. However, the exact mechanism by which the FLX (20 mg/kg, i.p.) produced more marked antidepressant effect in male is not explained by the present study. This might be one of the main reasons why the males are more vulnerable to the adverse effects of the SSRIs as compared to the females.

\section{CONCLUSION}

It has been concluded that the depression-like behavioral alteration was more in the female mice as compared to the male mice. In the present study, FLX exerted greater antidepressant effect in male mice as compared to the female mice. Furthermore, the antidepressant effect of FLX has been shown to be affected by the gender difference in TST, and therefore, the care should be taken while selecting the sex of animals used for the screening of the antidepressants-like activity by TST. Furthermore, the present study showed that the males are more susceptible to FLX as compared to the females, and therefore, the chances of getting adverse effects in the male are more as compared to the females.

\section{REFERENCES}

1. American Psychiatric Association. The Diagnostic and Statistical Manual of Mental Disorders. $4^{\text {th }}$ ed. Washington, DC: American Psychiatric Press; 1994.

2. Wong ML, Licinio J. From monoamines to genomic targets: A paradigm shift for drug discovery in depression. Nat Rev Drug Discov 2004;3(2):136-51.

3. Fava M, Kendler KS. Major depressive disorder. Neuron 2000;28(2):335-41. 
4. Nestler EJ, Barrot M, DiLeone RJ, Eisch AJ, Gold SJ, Monteggia LM. Neurobiology of depression. Neuron 2002;34(1):13-25.

5. Walia V. Role of enzymes in the pathogenesis of depression. J Crit Rev 2016b;3(2):1-6.

6. Rajkumar R, Mahesh R. The auspicious role of the 5-HT3 receptor in depression: A probable neuronal target? J Psychopharmacol 2010;24(4):455-69.

7. Rang HP, Dale MM, Ritter JM, Flower RJ. Pharmacology. $6^{\text {th }}$ ed. Philadelphia, PA: Elsevier; 2007.

8. Morilak DA, Frazer A. Antidepressants and brain monoaminergic systems: A dimensional approach to understanding their behavioural effects in depression and anxiety disorders. Int J Neuropsychopharmacol 2004;7(2):193-218.

9. Cryan JF, Mombereau C, Vassout A. The tail suspension test as a model for assessing antidepressant activity: Review of pharmacological and genetic studies in mice. Neurosci Biobehav Rev 2005;29(4-5):571-625.

10. Chermat R, Thierry B, Mico JA, Steru L, Simon P. Adaptation of the tail suspension test to the rat. J Pharmacol 1986;17(3):348-50.

11. Thierry B, Steru L, Chermat R, Simon P. Searching-waiting strategy: A candidate for an evolutionary model of depression? Behav Neural Biol 1984;41(2):180-9.

12. Cryan JF, Valentino RJ, Lucki I. Assessing substrates underlying the behavioral effects of antidepressants using the modified rat forced swimming test. Neurosci Biobehav Rev 2005;29(4-5):547-69.

13. Dixon AK. Ethological strategies for defence in animals and humans: Their role in some psychiatric disorders. Br J Med Psychol 1998;71:417-45.

14. Gilbert P, Allan S. The role of defeat and entrapment (arrested flight) in depression: An exploration of an evolutionary view. Psychol Med 1998;28(3):585-98.

15. Lucki I, Dalvi A, Mayorga AJ. Sensitivity to the effects of pharmacologically selective antidepressants in different strains of mice. Psychopharmacology (Berl) 2001;155:315-22

16. Porsolt RD, Bertin A, Jalfre M. Behavioral despair in mice: A primary screening test for antidepressants. Arch Int Pharmacodyn Ther 1977;229(2):327-36.

17. Willner $P$. The validity of animal models of depression. Psychopharmacology (Berl) 1984;83(1):1-16.

18. McHenry J, Carrier N, Hull E, Kabbaj M. Sex differences in anxiety and depression: Role of testosterone. Front Neuroendocrinol 2014;35(1):42-57

19. Steru L, Chermat R, Thierry B, Simon P. The tail suspension test: A new method for screening antidepressants in mice. Psychopharmacology (Berl) 1985;85(1):367-70.

20. Parker GB, Brotchie HL. From diathesis to dimorphism: The biology of gender differences in depression. J Nerv Ment Dis 2004;192(3):210-6.

21. Kessler RC, Berglund P, Demler O, Jin R, Merikangas KR, Walters EE Lifetime prevalence and age-of-onset distributions of DSM-IV disorders in the National Comorbidity Survey Replication. Arch Gen Psychiatry 2005;62(6):593-602.

22. Hayward C, Sanborn K. Puberty and the emergence of gender differences in psychopathology. J Adolesc Health 2002;30 4 Suppl:49-58.

23. Kessler RC, Walters EE. Epidemiology of DSM-III-R major depression and minor depression among adolescents and young adults in the National Comorbidity Survey. Depress Anxiety 1998;7(1):3-14.

24. Lewinsohn PM, Rohde P, Seeley JR. Major depressive disorder in older adolescents: Prevalence, risk factors, and clinical implications. Clin Psychol Rev 1998;18(7):765-94.

25. Young EA, Lopez JF, Murphy-Weinberg V, Watson SJ, Akil H. Hormonal evidence for altered responsiveness to social stress in major depression. Neuropsychopharmacology 2000;23(4):411-8.

26. Benmansour S, Piotrowski JP, Altamirano AV, Frazer A. Impact of ovarian hormones on the modulation of the serotonin transporter by fluvoxamine. Neuropsychopharmacology 2009;34(3):555-64.

27. Estrada-Camarena E, Fernández-Guasti A, López-Rubalcava C. Antidepressant-like effect of different estrogenic compounds in the forced swimming test. Neuropsychopharmacology 2003;28(5):830-8.

28. Rocha BA, Fleischer R, Schaeffer JM, Rohrer SP, Hickey GJ. 17 Beta-estradiol-induced antidepressant-like effect in the forced swim test is absent in estrogen receptor-beta knockout (BERKO) mice. Psychopharmacology (Berl) 2005;179(3):637-43.

29. Dhir A, Kulkarni SK. Antidepressant-like effect of 17 beta-estradiol Involvement of dopaminergic, serotonergic, and (or) sigma-1 receptor systems. Can J Physiol Pharmacol 2008;86(10):726-35.

30. Barros HM, Ferigolo M. Ethopharmacology of imipramine in the forced-swimming test: Gender differences. Neurosci Biobehav Rev 1998;23(2):279-86
31. Frye CA, Petralia SM, Rhodes ME. Estrous cycle and sex differences in performance on anxiety tasks coincide with increases in hippocampa progesterone and 3alpha,5alpha-THP. Pharmacol Biochem Behav 2000;67(3):587-96

32. Halbreich U, Kahn LS. Role of estrogen in the aetiology and treatment of mood disorders. CNS Drugs 2001;15(10):797-817.

33. Albertazzi P, Natale V, Barbolini C, Teglio L, Di Micco R. The effect of tibolone versus continuous combined norethisterone acetate and oestradiol on memory, libido and mood of postmenopausal women: A pilot study. Maturitas 2000;36(3):223-9.

34. Goodnick PJ, Chaudry T, Artadi J, Arcey S. Women's issues in mood disorders. Expert Opin Pharmacother 2000;1(5):903-16.

35. Walia V. Influence of stress and fluoxetine on immobility period of mice in tail suspension test and forced swim test. Asian J Pharm Clin Res 2016;9(2):1-4

36. Mendels J. The acute and long-term treatment of major depression. Int Clin Psychopharmacol 1992;7 Suppl 2:21-9.

37. Xue R, Jin ZL, Chen HX, Yuan L, HeXH,Zhang YP, et al. Antidepressantlike effects of $071031 \mathrm{~B}$, a novel serotonin and norepinephrine reuptake inhibitor. Eur Neuropsychopharmacol 2013;23(7):728-41.

38. Hyde JS, Mezulis AH, Abramson LY. The ABCs of depression Integrating affective, biological, and cognitive models to explain the emergence of the gender difference in depression. Psychol Rev 2008;115(2):291-313.

39. Amore M, Di Donato P, Berti A, Palareti A, Chirico C, Papalini A, et al. Sexual and psychological symptoms in the climacteric years. Maturitas 2007;56(3):303-11.

40. Soares CN. Depression during the menopausal transition: Window of vulnerability or continuum of risk? Menopause 2008;15:207-9.

41. Frye CA, Wawrzycki J. Effect of prenatal stress and gonadal hormone condition on depressive behaviors of female and male rats. Horm Behav 2003;44(4):319-26

42. Young EA, Korszun A. The hypothalamic-pituitary-gonadal axis in mood disorders. Endocrinol Metab Clin North Am 2002;31(1):63-78.

43. Young EA. Sex differences and the HPA axis: Implications for psychiatric disease. J Gend Specif Med 1998;1(1):21-7.

44. Young EA, Midgley AR, Carlson NE, Brown MB. Alteration in the hypothalamic-pituitary-ovarian axis in depressed women. Arch Gen Psychiatry 2000;57(12):1157-62.

45. Young EA, Ribeiro SC, Ye W. Sex differences in ACTH pulsatility following metyrapone blockade in patients with major depression. Psychoneuroendocrinology 2007;32(5):503-7.

46. Marvan ML, Chavez-Chavez L, Santana S. Clomipramine modifies fluctuations of forced swimming immobility in different phases of the rat estrous cycle. Arch Med Res 1996;27:83-6.

47. Marván ML, Santana S, Chávez Chávez L, Bertran M. Inescapable shocks accentuate fluctuations of forced swimming immobility in different phases of the rat estrous cycle. Arch Med Res 1997;28(3):369-72.

48. Simonds VM, Whiffen VE. Are gender differences in depression explained by gender differences in co-morbid anxiety? J Affect Disord 2003;77(3):197-202.

49. Yonkers KA, Ellison JM. Anxiety disorders in women and their phamacological treatment. In: Jensvold MF, Halbreich U, Hamilton JA, editors. Psychopharmacology and Women: Sex, Gender and Hormones. Washington, DC: American Psychiatric Press; 1996. p. 261-85.

50. Biegon A, Bercovitz H, Samuel D. Serotonin receptor concentration during the estrous cycle of the rat. Brain Res 1980;187(1):221-5.

51. Biegon A, McEwen BS. Modulation by estradiol of serotonin receptors in brain. J Neurosci 1982;2(2):199-205.

52. Gallucci WT, Baum A, Laue L, Rabin DS, Chrousos GP, Gold PW, et al. Sex differences in sensitivity of the hypothalamic-pituitaryadrenal axis. Health Psychol 1993;12(5):420-5.

53. Handa RJ, Burgess LH, Kerr JE, O'Keefe JA. Gonadal steroid hormone receptors and sex differences in the hypothalamo-pituitary-adrenal axis. Horm Behav 1994;28(4):464-76.

54. Jezová D, Juránková E, Mosnárová A, Kriska M, Skultétyová I Neuroendocrine response during stress with relation to gender differences. Acta Neurobiol Exp (Wars) 1996;56(3):779-85.

55. Berman NE, Puri V, Chandrala S, Puri S, Macgregor R, Liverman CS, et al. Serotonin in trigeminal ganglia of female rodents: Relevance to menstrual migraine. Headache 2006;46(8):1230-45.

56. Pecins-Thompson M, Brown NA, Kohama SG, Bethea CL. Ovarian steroid regulation of tryptophan hydroxylase mRNA expression in rhesus macaques. J Neurosci 1996;16(21):7021-9.

57. Pecins-Thompson M, Brown NA, Bethea CL. Regulation of serotonin re-uptake transporter mRNA expression by ovarian steroids in rhesus macaques. Brain Res Mol Brain Res 1998;53(1-2):120-9. 
58. Smith LJ, Henderson JA, Abell CW, Bethea CL. Effects of ovarian steroids and raloxifene on proteins that synthesize, transport, and degrade serotonin in the raphe region of macaques. Neuropsychopharmacology 2004;29:2035-45.

59. Bethea CL, Lu NZ, Gundlah C, Streicher JM. Diverse actions of ovarian steroids in the serotonin neural system. Front Neuroendocrinol 2002;23(1):41-100.

60. Osterlund MK, Hurd YL. Acute 17 beta-estradiol treatment downregulates serotonin 5HT1A receptor mRNA expression in the limbic system of female rats. Brain Res Mol Brain Res 1998;55:169-72.

61. D'Souza DN, Zhang Y, Damjanoska KJ, Carrasco GA, Sullivan NR, Garcia F, et al. Estrogen reduces serotonin-1A receptor-mediated oxytocin release and Galpha(i/o/z) proteins in the hypothalamus of ovariectomized rats. Neuroendocrinology 2004;80(1):31-41.

62. Osterlund MK, Halldin C, Hurd YL. Effects of chronic 17beta-estradiol treatment on the serotonin 5-HT(1A) receptor mRNA and binding levels in the rat brain. Synapse 2000;35(1):39-44.

63. Amin Z, Canli T, Epperson CN. Effect of estrogen-serotonin interactions on mood and cognition. Behav Cogn Neurosci Rev 2005;4(1):43-58.

64. Estrada-Camarena E, Fernández-Guasti A, López-Rubalcava C. Interaction between estrogens and antidepressants in the forced swimming test in rats. Psychopharmacology (Berl) 2004;173(1-2):139-45.

65. Frey BN, Lord C, Soares CN. Depression during menopausal transition: A review of treatment strategies and pathophysiological correlates. Menopause Int 2008;14(3):123-8. 